Pace University

DigitalCommons@Pace

Wilson Center for Social Entrepreneurship

Academic, Policy and Research Centers

Summer 7-12-2016

\title{
The Challenges to Social Entrepreneurship in Brazilian Art/Handicraft Organizations: Today and in the Future
}

Claudia Green $\mathrm{PhD}$

Pace University, cgreen@pace.edu

Adnan Dhiyan

Pace University

Follow this and additional works at: http://digitalcommons.pace.edu/wilson

Part of the Business Administration, Management, and Operations Commons, and the Entrepreneurial and Small Business Operations Commons

\section{Recommended Citation}

Green, Claudia PhD and Dhiyan, Adnan, "The Challenges to Social Entrepreneurship in Brazilian Art/Handicraft Organizations: Today and in the Future" (2016). Wilson Center for Social Entrepreneurship. Paper 33.

http://digitalcommons.pace.edu/wilson/33 


\title{
THE CHALLENGES TO SOCIAL ENTREPRENEURSHIP IN BRAZILIAN ART/HANDICRAFT ORGANIZATIONS: TODAY AND IN THE FUTURE
}

\author{
Claudia G. Green \\ Pace University, USA \\ cgreen@pace.edu \\ Adnan Dhiyan \\ Pace University, USA \\ adnan.dhiyan@pace.edu
}

\begin{abstract}
O Sol is a Brazilian art/handicraft social entrepreneurship cooperative that began over 50 years ago. The trained artists produce authentic art/handcraft that is sold to tourists in Rio de Janeiro. The organization promotes human development and authentic Brazilian culture through the production and selling of art/handicrafts. However, today it is at risk economically, socially and culturally. The experience of O Sol is not uncommon today due to the globalization and mass production of authentic art tourism.
\end{abstract}

Key Words: art, authentic, handicraft, tourism, social entrepreneur, non-profit, Brazil, corporate social responsibility, sustainability, social value, shared value

\section{What is $\mathbf{O}$ Sol?}

O Sol, an art and handicraft non-profit organization in Rio de Janeiro, a city that continues to be a popular global destination. With recent global exposure due to the hosting of the World Cup 2014 and Olympics 2016, it is expected that there will be a robust market for authentic Brazilian art and handicraft throughout the country yet $\mathrm{O}$ Sol is a struggling non-profit organization facing a number of challenges.

O Sol, a Brazilian non profit, social entrepreneurship that survived Rio de Janeiro's dark days including the country's fascist government, the relocation of the capital to Brasilia, the shift of financial markets from Rio de Janeiro to Sao Paulo and the expansion of favelas. With the recent media attention on the 2014 World Cup and Olympics 2016, there has been increased focus on tourism to Rio de Janeiro. It is known that shopping and specifically authentic art is a common activity for many tourists (Paige \& Littrell, 2003). After 50 years of being an entrepreneurial, non profit operation providing authentic art to tourists and providing employment to many people who live in the favelas, O Sol is at risk economically, socially and culturally. The mission of a social entrepreneur is "to solve a social problem", such as reduction of poverty, through harnessing market forces, as opposed to providing charity. Sloan et al (2014) note that only $2 \%$ of published research in hospitality and tourism has addressed the concept of entrepreneurship as a vehicle for change.

\section{The challenges to art tourism}

Shopping is one of the top tourist activities which generates tourism revenue and contributes to economic development (Paige \& Littrell, 2003). In particular, tourists are interested in authentic arts and handicrafts because they involve the artisan, the method and often local materials (authentic art tourism). Souvenirs, on the other hand, are the mass produced items of lesser quality and craftsmanship. The authenticity of a craft is based on its workmanship, aesthetics and utility, uniqueness, genuineness as well as cultural and historical integrity (Littrell, Anderson \& Brown, 1993). The characteristics of the shopping experience and the craftsman contribute to the overall authenticity as well. Littrell et al (1993) found that tourists have differing definitions of authentic art based on their age, stage of travel experience and style of tourism, but not on their gender.

Globally fewer and fewer older generations of artisans are passing the art of their craft to the younger 
generations who are searching for better paying and more consistent sources of income. This phenomenon has also been documented in countries such as Brazil, Morocco, Mexico, and Peru. In his study of Third World artisans in Central America, Africa and Asia, Scares (2015) reported that globalization has increased the precarious existence of viable artisan cooperatives due to mass production of crafts, shifts in styles, fashions and tastes and increased global competition. Scares also noted that both government and nongovernment organizations with the mission of supporting art often have policies and programs that are less than effective. For instance, these organizations tend to overlook the needs of the craft worker, fail to incorporate local knowledge in the employment practices and often show disdain for the marginal workers. Only a few countries, specifically, Germany, the USA, the UK and France, have been successful in the development of commodity chains that link the artisans, wholesalers and department stores.

\section{The O Sol Model and Mission}

In 1965, O Sol was founded by a female, Brazilian social entrepreneur as a non-profit organization with the mission to preserve art, promote human development and dignity, and encourage the use of hands to achieve autonomy. Also included in its mission is a focus on teaching and sustaining traditional Brazilian handicraft skills to foster personal engagement and human development. The organization allows women and men of any age who are in need of income to learn the crafts of ceramics, weaving, and painting. They believe that this personal engagement will bring about societal, personal, and technical growth of the people that will spread into their communities. In 1978 O Sol organized the first meeting of Technical and Crafts Artisans Cooperative representatives from around the country. They have acknowledged their social responsibility and recognized their mission to empower people to work on their hand-crafted artistic techniques and focus on the greater financial and personal investment.

O Sol's mission is to "Promote and encourage humanistic development in socially and economically vulnerable people through the education and training in craft techniques, through productive actions in art and culture that allow for the creation of greater opportunities related to work and income." In addition, their goal is "To be, by 2016, the standard for job creation and education in the craft sector." To achieve their mission, they provide:

- Education in technical craft

- Enhancement techniques and practices of craftsmen

- Product flow in its permanent craft fair / store

O Sol provides workshops that train students how to produce art and handicrafts. They have a permanent craft fair; mezzanine; inventory; library; administration rooms; meeting room; space for lectures, group activities and meetings; small parking area. O Sol offers classes in nine (9) different modules which include embroidery, pottery, natural fiber basketry, sewing, drawing/painting, wood cutting, macramé, weaving and word carving. Based on demand, they also offer jewelry and knitting classes. The goals of the courses are to train residents in craft techniques and encourage creativity with the expectation that residents will be able to generate new and better opportunities for earning income. They encourage the entrepreneurial attitude and also demonstrate how to market, brand and ship products.

\section{Situations Analysis}

1. Competition in the sector. O Sol is located in semi-residential area of Jardin Botannica in Rio de Janeiro. It is not on a main thoroughfare and has very little foot traffic. Social entrepreneurship in art and handicraft is common in Brazil. As a matter of fact, there are non-profit organizations using the model of teaching people to make art in many of the favelas. Another example organization called, Asta, purchases handicrafts at a fair price from 60 women in the 33 communities around Rio and then re-sells them to corporate clients online and in their fair trade shop in Laranjeiras. Part of their funding comes from a microfinance company that loans the money up front for the materials needed to make the crafts. Other markets include the Hippie Market in Ipanema, the Babilônia Feira Hype in Gávea, the Mercado das Pulgas at Largo dos 
Guimarães in Ipanema, the Feira de Antiguidades at Praça Santos and the Feira Nordestinain the Zona Norte.”

One way to identify the competitors of O Sol is to search tourism guidebooks where authentic art and handicraft shops might be mentioned. A review of the major travel guides online and in print demonstrated that O Sol only has minimal inclusion in the major travel guides written in English. Fodor's Online Guide to Rio de Janeiro has a listing of neighborhoods with what to do in each specific neighborhood include Ipanema, Copacabana, Centro, Gloria and Catete, Leblon, Santa Teresa and Lapa, Flamengo and Botofugo. However, there was no mention of Jardin Botanica (Botanical Gardens) and O Sol was not listed under the general tab of Shopping. O Sol can only be found if you know the name "O Sol" and type it in the search engine for the site. The address, phone number and map are provided with a link that does not work and goes to a website entirely in Portuguese. Frommer's Guide has no comment about O Sol in their shopping or in a search of the site. In the Lonely Planet Guide, there is mention of O Sol under shopping with the following narrative: "O Sol is run by a non-profit social welfare organization. This delightful store displays the works of regional artists and sells Brazilian folk art in clay, wood and porcelain. It also sells baskets and woven rugs.”

Rough Guide Rio shows shopping recommendations that mention other markets in Rio, but do not mention O Sol. "Of Rio's markets, the so-called Hippie Market in Ipanema has nowadays become very touristy; much better is the Babilônia Feira Hype in Gávea, the Mercado das Pulgas at Largo dos Guimarães in Ipanema (second Sat of the month 2-8pm; handicrafts), or the Feira de Antiguidades at Praça Santos (Sun 9am-5pm; bric-a-brac). For arts, crafts and food from Brazil's northeast, there's nowhere better than the Feira Nordestinain the Zona Norte."

In its online publication about handicrafts in Rio, National Geographic mentions Casa de Artesanato, showroom for Rio de Janeiro city and state artisans; FUNAI Craft Shop, which is part of Museu do Índio. In Botafogo featuring objects made by indigenous tribes; Cachaçaria Petisco da Vila produces artisanal cachaça (sugar cane brandy); and Marcelo Armstrong's Favela Tour which stops at Feira de Artesanato da Rocinha, the handicraft market inside the Rocinha favela (shanty town); and finally, the Ipanema Hippie Fair outdoor market featuring locally made art and gifts. There was no mention of O Sol.

\section{Socio-economic environment.}

O Sol is accountable to its mission to produce social good with new and better ways for its students to improve their skills and become entrepreneurs. They have been successful in interacting with related institutions and communities. In April 2012, they started a series of visits, promoting dialogue and program assessment, necessary for the development of new partners and the preparation and development of two new projects. They participate with institutions, groups and residents of communities from different regions of Rio de Janeiro. O Sol, the typical handicraft school, hosts a minimum of 240 students and provides them with sufficient materials and transportation. However, to cover these expenses they need a budget 30\% higher than their current budget. The lack of funding has resulted in a 30\% reduction in the potential 240 students. The Program Coordinator stated that $75 \%$ of the profits made on handicrafts goes to the artisans. Another challenge facing $\mathrm{O}$ Sol is the lack of consistent year round sales with Christmas being the peak season. Artisan handicraft production is time consuming. The Program Coordinator said lower sales could be attributed to the fact that many authentic art and handicrafts are being copied, produced in mass and sold at much cheaper prices in other countries of the world.

\section{Partner and stakeholders.}

O Sol has partnered with the following local, state, national and international organizations: Ministry of Foreign Affairs, Ministry of Social Welfare - PAB / Brazilian Handicraft program - Ministry Culture, UNESCO, Rio de Janeiro Botanical Garden, National History Museum, Folklore Museum Edson Carneiro, Museu Casa do Pontal, Indian Museum, the Goeldi Museum, National Museum - 
UFRJ, CNC / National Confederation of Commerce, SESC / Social Service of Commerce, SENAC / Commercial Training Service, SENAI / National Industrial Apprenticeship Service, Texaco, Klabin Fabricadora Pulp and Paper, Rio Design Center. Other stakeholders include O Sol's target population, working age young people and adults with low education and living at the poverty line in the many favelas in Rio. Some of the employees and artist teachers are paid, but most of them are volunteers.

In the 1995 during one of Brazil's periods of economic stagnation and high inflation, a non-profit named Brazil Institute of Board Members, was organized to set guidelines for the governance of organizations. By 1999, the non-profit organization had changed its name to Instituto Brasileiro de Governanca Corporativa or the Brazilian Institute for Corporate Governance (IBGC). Based on the guidelines, it was recommended that Boards of Directors should have a minimum of five (5) members and a maximum of eleven (11) with at least $20 \%$ being outsiders to the organization (Eddis, Grau, Miller, Moklestad \& Oskvig, 2013). O Sol has a Board of Directors and a Management Team. The Board plays the role of a watchdog for the non-profit in that they are responsible for the strategic direction of the organization and the maintenance of its cultural identity. It is comprised of eight (8) people including two (2) local artists who were friends with the founder, two (2) small business owners, two (2) people who were wealthy philanthropists, one (1) person with accounting and financial background and one (1) of the sisters of the founder of the organization. IBGC also suggests that the Board of Directors organize their work into committee such as the audit committee, the finance committee, the human resources or compensation committee and the sustainability committee (Eddis, et al, 2013). However, O Sol's Board does not adhere to this suggestion. Basically, as a group, the Board makes decisions on auditing, finance, human resources and sustainability. The Board of Directors is totally voluntary, unpaid and meets only once every financial quarter. The planning is year by year and there is no long term strategic plan.

There are three paid employees on the management team: a Program Coordinator and two Assistant Managers. Day-to-day operational planning is done by the management team. They supervise six (6) volunteers who work in the retail shop where they also take inventory. One of the Assistant Managers prices the art and handicraft items and assures that payments are made to the specific artisans for their work and has primary control of the retail shop and sales. The other Assistant Manager is responsible for the art workshops, ordering supplies, scheduling workshops and supervising the $10 \mathrm{art} / \mathrm{handicraft}$ teachers who are paid on a per class basis. The control and accountability mechanism is very loose and is the responsibility of the Program Coordinator. There is concern among the founder, Board of Directors and Management Team that the financial health of the organization is at risk.

\section{Cultural environment.}

Recent research supports the idea that globalization is having a negative impact on artisan communities because of the global mass production of art objects (2003). Brazil is among the Third World countries where that impact is being felt. The Program Coordinator indicated that O Sol has had reduced sales due to competition. In addition to the financial threat of competition, there is a cultural threat to future of authentic Brazilian crafts as they are being replaced by manufactured products. In her article on art in Brazil, Barbosa (2002) contends that art education prepares people to not "be strangers" in their own environment and allows personal expression and an opportunity for cultural identification by citing several examples of successful projects involving poor young people and adults. She indicated that although art education was required by law in 1971, it has been replaced with literature as an art in Brazilian schools. According to Barbosa, "In Brazil all the non-governmental organizations (NGOs) that have been successful in their work with disadvantaged residents use art." $\mathrm{O}$ Sol is attempting to not only contribute to the financial wellbeing but also the cultural integrity of Brazilian handicrafts. That attempt is being challenged by lower priced, less authentic alternative products.

\section{Legal environment.}

Because $\mathrm{O}$ Sol is a non-profit organization, it is subject to a different set of standards. Political debates have ensued regarding the role of non-profit organizations in Brazil. It remains unclear as to who is 
responsible for poverty and improving conditions within society. Research suggests that the non-profit sector has successfully mobilized material resources and has had a positive influence on society. O Sol receives no funding from the government. No grants are being provided. Primarily the organization serves people who live in the favelas. Unfortunately, the government is responsible for the displacement of many favela residents as it has tried to control the violence and improve living conditions recently in preparation for the 2014 World Cup and 2016 Olympics. Currently, O Sol offers regular courses in handicraft workshops and production centers to residents who live close by in many favelas including Rocinha, Vidigal, Dona Marta, Garden, and Vila Canoas. The regulatory environment for business in Brazil is deeply rooted in protectionism. However, non-government organizations are subject to a different code entirely. Classifying non-profit organizations in Brazil has been proven to be challenging, as the term "non-profit sector" is not widely recognized. Little information is available on these organizations and their relationship to the government. Five broad categories are recognized. They are as follows: civil societies, associations, charitable organizations, non-government organizations and foundations. These categories are not clearly defined nor are they descriptive. O Sol could easily fall into multiple categories. In his research on NGOs in Brazil, TorpeuSaboe (2015) said they began during the military rule in the 1960s and 1970s. They continued to grow during the 1980s and made contribution to the democratic transition in Brazil. In 1993, Brazil had more NGOs than any other country in the developing world. However, he finds through statistical analysis that the higher the number of NGOs in a country the greater correlation with lower government spending on social issues.

\section{Opportunities}

Since the 2007 announcement that Rio would be hosting World Cup 2014, there has been an increase of 300,000 tourists annually since then and this growth is expected to continue until 2017, due to the hosting of the 2016 Olympics. In 2015, after the World Cup 2014, an official of the Rio de Janeiro Convention and Visitor's Bureau said "We are not focused on the 2016 Olympics, it is happening. Our focus now is the rebranding of Rio as a major convention and meeting destination to absorb the infrastructure and hotels rooms that we have built for the two mega sports events.” (M. Nagey, personal communication, March Rio Convention and Visitors Bureau, March 20, 2015).

In recent years, the focus on mega sports events in Rio has resulted in billions of dollars being invested in infrastructure for sporting, tourists, security and transportation (Gaffney, 2010) although "social inclusion" has been said to be part of the initiatives, it is often to the contrary. According to Gaffney, large construction projects have resulted in the displacement of many favela residents and the disruption of their social and economic networks.

Credits: This case study was funded in part by the Pace University Wilson Center for Social Entrepreneurship and the Lubin School of Business. 


\section{Teaching notes}

\section{Claudia Green}

O Sol is a social entrepreneurship that has the mission of teaching traditional Brazil art skills and techniques to indigent people from the favelas of Rio de Janeiro. The overall goal is to provide the opportunity for residents of the favelas to have a source of income and to maintain the traditional authentic Brazilian art culture.

\section{Teaching Objectives}

This case study can be used to inform students about social entrepreneurship, creating shared value, creating social value, corporate social responsibility and the challenges facing authentic art tourism globally. The target audience is college students in upper level or graduate level tourism management class. There are four (4) Teaching Options that include Assignments incorporating Articles and Videos followed by Discussion Questions which reinforce the Teaching Objectives.

After reading and analyzing this case study and supporting articles/videos, students should be able to:

1) describe the characteristics and environments of social entrepreneurs;

2) discuss the process of creating shared values in organizations;

3) outline the framework for creating social value; and

4) identify the challenges facing authentic art tourism.

\section{Teaching approach}

(Instructors may chose to use all four (4) of the teaching options or fewer depending on the course level and time available).

1. Assign the case study and selected articles to be read in Teaching Options 1, 2, 3 and/or 4 before coming to class. The Case Study Questions should be posted in an online format for students to read, review and take notes upon before coming to class (3 hours preparation out of class).

2. In class, the instructor will lead a discussion of the case, in general, and show the videos that support each of the Teaching Options (60 minutes in class).

a. Teaching Option \#1 Evaluating the Internal and External Environments of Non-Profits;

b. Teaching Option \#2 Creating Shared Values: Videos- "Creating Shared Value:

Connecting Business, Societal Value and Opportunity" and "People, Planet, Profit, the Triple Bottom Line".

c. Teaching Option\# 3 Social Entrepreneurs Creating Social Value: Video- "What is a social entrepreneur?”

d. Teaching Option \#4 Authentic Art Tourism: Video- “ China's giant oil painting copy shop - BBC News".

3. Then, the students will be organized in teams of no more than 5 students where they respond to and debate the Case Study Questions (30 minutes in class).

4. After 30 minutes, the instructor will lead a discussion on each of the Teaching Options and students will be expected to "report out" on how their team responded based on case study, articles, and videos (30 minutes in class). 


\section{Teaching Option \#1: Evaluating the Internal and External Environments of Non-Profits}

\section{Background reading/viewing}

Students should read the article by Turbide (2012) in preparation for a discussion related to the following questions. Turbide (2012) proposed and tested a model for assessing/monitoring the complex internal and external environment within which social entrepreneurs in arts organizations must operate. For the purposes of analysis of O Sol, Turbide's model in Figure 1 Systematic Framework for Evaluating the Internal and External Environments of Non-Profit Organizations will be used to analyze this case (Turbide, 2012).

\section{Articles}

Turbide, J. (2012). Can Good Governance Prevent Financial Crises in Art Organizations. International Journal of Art Management. 14 (2), 3-17.

\section{Recommended case study questions}

1. Using Turbide's model of how arts organizations operate, analyze O Sol. Use the table below to systematically evaluate $O$ Sol's international and external environments.

\begin{tabular}{|l|l|l|l|}
\hline & Environment & Challenge & Potential solution \\
\hline $\begin{array}{l}\text { Competition in the } \\
\text { sector }\end{array}$ & & & \\
\hline Socio-Economic & & & \\
Environment & & & \\
\hline Partners \& & & & \\
Stakeholders & & & \\
\hline Cultural & & & \\
Environment & & & \\
\hline Legal Environment & & & \\
\hline
\end{tabular}


Figure 1 Systematic Framework for Evaluating the Internal and External Environments of NonProfit Organizations.

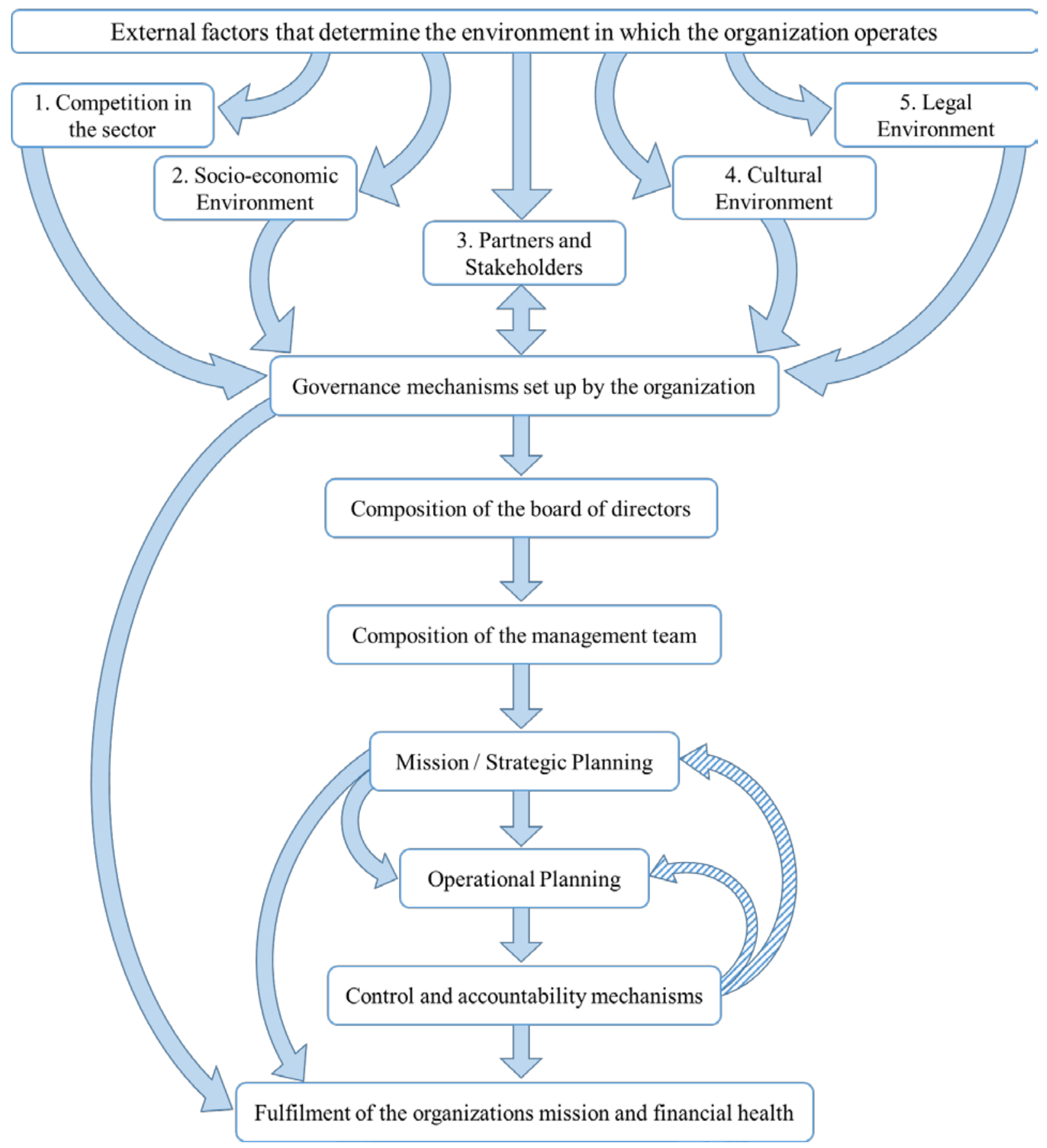

Source: Turbide, 2012 


\section{Teaching Option \# 2 Creating Shared Value}

\section{Background reading/viewing}

Students should read the article by Porter and Kramer's (2011) in preparation for a discussion related to the following questions. The videos should be viewed in class to stimulate discussion.

Porter, M. E. \& M. R. Kramer. (2011). Creating Shared Value. Harvard Business Review 89(122)(January-February).

Video: Creating Shared Value: Connecting Business, Societal Value and Opportunity https://youtu.be/kF3wsT7FG7k

Video: People, Planet, Profit, the triple bottom line https://youtu.be/d95qkMxSfm0

\section{Recommended case study questions}

1. Define corporate social responsibility.

2. How does the triple bottom line audit of people, place and profit relate to the concept of corporate social responsibility?

3. Explain the difference between corporate social responsibility and creating shared value as outlined in the article. 


\section{Teaching Option \#3 Creating Social Value}

\section{Background reading/viewing}

Students should read the articles by Sigala's (2015a\&b) in preparation for a discussion related to the following questions. The video should be viewed in class to stimulate discussion.

Sigala, M. (2015a). Social value co-creation: findings and implications from Mageires the social restaurant. The fourth The 2015 Naples Forum on Service, "Service Dominant Logic, Network \& Systems theory and Service Science: Integrating three perspectives for a new service agenda.," hosted and organized by the University of Salerno and The University of Naples "Frederico II" Naples, Italy, June 9-12, 2015

Sigala, M. (2015b). The role of franchising in generation social value and transformation: The case of LeMat. The $14^{\text {th }}$ International Research Symposium on Service Excellent in Management (QUIS14 symposium) “Collaborative innovations in the network Environment” organized by the Center for Service Marketing and Management (CSMM), Fudan University, China Europe International Business School (CEIBS), Karlstad University, Sweden, Arizona State University, USA and Cornell University, USA. Shanghai, China, June 18-21, 2015.

Video: What is a social entrepreneurship? https://youtu.be/1ecKK3S8DOE

\section{Recommended case study questions}

1. Is O Sol a social entrepreneurship? Explain.

2. According to the concept of "learning the market", what are the three capabilities that a social entrepreneur should develop?

3. Considering the case study of O Sol, do you think the organization has developed the three capabilities? Explain and give examples.

4. How could developing these three capabilities result is O Sol being more sustainable and less at risk of closing its doors? 


\section{Teaching Option\#4 Authentic Art Tourism}

\section{Background reading/viewing}

Students should read the articles by Stoddard, Evans and Shao (2012), Scrase (2003) and Anderson and Littrell (1995) in preparation for a discussion related to the following questions. The video should be viewed in class to stimulate discussion.

Stoddard, J.E, M.R.Evans \& X.Shao (2012). Marketing arts and crafts: Exploring the connection between hedonic consumption, distribution channels and tourism. International Journal of Hospitality and Tourism Administration. 13, 95-108.

Scrase,, T. J. (2003) Precarious production: Globalisation and artisan labour in the Third World, Third World Quarterly, 24:3, 449-461

Anderson, L. F., \& Littrell, M. A. (1995). Souvenir-purchase behavior of women tourists. Annals of Tourism Research, 22, 328-348.

Video: China's giant oil painting copy shop - BBC News https://youtu.be/qZVJTW4jpck

\section{Recommended case study questions}

1. What is the difference between a craft and a souvenir?

2. What motivates a tourist to purchase crafts?

3. Should O Sol consider setting up an online site to sell their crafts globally? Why? Why not?

4. What are the threats to authentic art tourism? What are some steps that could be taken to reduce these threats?

5. How should O Sol change their marketing strategy, or, should they?

\section{REFERENCES}

Anderson, L. F., \& Littrell, M. A. (1995). Souvenir-purchase behavior of women tourists. Annals of Tourism Research, 22, 328-348.

Barbosa, A. M. Social Reconstruction Through Art. Prospects, vol. XXXII, no. 4, December 2002.

BBC News China's giant oil painting copy shop - BBC News https://youtu.be/qZVJTW4jpck Retrieved October 2, 2015.

Eddis, C., M. Grau, J.Miller, M Moklestad, and J. Oskvig. (2013). Corporate Governance Comparison and Analysis: Brazil. Drake Management Review, 3 (1), 81-102.

Elkington, J. (1997) Cannibals with Forks: the Triple Bottom Line of the $21^{\text {st }}$ Century Business. Gabriola Island, B.C Canada.: New Society Publishers.

Fodor's Online Guide to Rio de Janeiro (2015). http://www.fodors.com/world/southamerica/brazil/rio-de-janeiroober Retrieved on October 2, 2015.

Frommer's Guide Rio (2015). http://www.frommers.com/destinations/rio-de-janeiro Retrieved on October 2,2015.

Gaffney, C. (2010). Mega-events and socio-spatial dynamics in Rio de Janeiro, 1919-2016. Journal of Latin American Geography. 9(1). 7-29.

Littrell, M. A., Anderson, L. F., \& Brown, P. J. (1993). What makes a souvenir authentic? Annals of 
Tourism Research, 20(1), 197-215.

Lonely Planet Rio de Janeiro. (2015). http://www.lonelyplanet.com/brazil/rio-de-janeiro Retrieved October 2, 2015.

Mair, J. \& I. Marti (2006). Social entrepreneurship research: A source of explanation, prediction and delight. Journal of World Business, 41 (1), 36-44.

National Geographic Rio de Janeiro. (2015). http://travel.nationalgeographic.com/travel/cityguides/rio-de-janeiro-brazil/ Retrieved on October 2, 2015.

Paige, R. C., \& Littrell, M. A (2003). Tourism activities and shopping preferences. Journal of Shopping Center Research, 10(2), 7-25.

Porter, M. E., \& Kramer, M. R. (2011). Creating shared value. Harvard Business Review, 89(1/2), 6277.

Rough Guide Rio (2015). http://www.roughguides.com/shop/rough-guides-snapshot-brazil-rio-janeiro/ Retrieved on October 2, 2015

Scrase, T. J. (2003) Precarious production: Globalisation and artisan labour in the Third World, Third World Quarterly, 24:3, 449-461.

Sigala, M. (2015a). Social value co-creation: findings and implications from Mageires the social restaurant. The fourth The 2015 Naples Forum on Service, "Service Dominant Logic, Network \& Systems theory and Service Science: Integrating three perspectives for a new service agenda.," hosted and organized by the University of Salerno and The University of Naples "Frederico II" Naples, Italy, June 9-12, 2015.

Sigala, M. (2015b). The role of franchising in generation social value and transformation: The case of LeMat. The $14^{\text {th }}$ International Research Symposium on Service Excellent in Management (QUIS14 symposium) "Collaborative innovations in the network Environment" organized by the Center for Service Marketing and Management (CSMM), Fudan University, China Europe International Business School (CEIBS), Karlstad University, Sweden, Arizona State University, USA and Cornell University, USA. Shanghai, China, June 18-21, 2015.

Sloan, S., W. Legrand, \& C. Simons-Kaufmann. (2014). A survey of social entrepreneurial community-based hospitality and tourism initiatives in developing economies: A new business approach for industry. Worldwide Hospitality and Tourism Themes, 6(1), 51-61.

Stoddard, J.E, M.R. Evans \& X. Shao (2012). Marketing arts and crafts: Exploring the connection between hedonic consumption, distribution channels and tourism. International Journal of Hospitality and Tourism Administration, 13, 95-108.

Torpeu-Saboe, N. (2015). Does NGO presence decrease government spending? A look at municipal spending on social services in Brazil, World Development 74, 479-488.

Turbide, J. (2012) Can Good Governance Prevent Financial Crises in Art Organizations. International Journal of Art Management, 14 (2), 3-17. 